\title{
Exploitation of Climate Resilient Minor Tropical Fruit Crops for Nutritional and Livelihood Security in Fiji Islands
}

\author{
A.K. Tiwari ${ }^{1 *}$, D.S. Mishra ${ }^{2}$, Salesh Kumar ${ }^{1}$ and D.M.C. Champathi Gunathilake ${ }^{1}$ \\ ${ }^{1}$ Fiji National University, College of agriculture, Fisheries and forestry, Koronivia, \\ Fiji Islands \\ ${ }^{2}$ Central Horticultural Experiment Station, Godhra, India \\ *Corresponding author
}

\section{A B S T R A C T}

Keywords

Minor fruits,

Sustainable,

Livelihood,

Value addition

Article Info

Accepted:

15 October 2018

Available Online:

10 November 2018
Fiji enjoys a tropical maritime climate, but a sizeable areas of this pacific islands also comes under dry areas, earlier sugarcane was grown on large scale, but due to constraints now it is slowly substituted by other enterprise, among them horticulture has emerged as major enterprise, but establishment of orchard is a long term investment and its fruit comes many year after planting, so a careful need is to be taken before establishment of orchard, a number of minor tropical fruits are grown in Fiji islands like ber, custard apple, bael, guava, jamun, jackfruit, kavika, lasora, nandau, mulberry, passion fruit, starapple, tamarind, tarawau, mulberry who are not only rich in their nutritional value, and can be utilized for preparation of various nutrient enriched product, providing earning to the farmer as well as processor. These minor fruits has inherent capacity to survive and perform well under changing climate, and inclement weather but no attention has been paid to these crops, popularization of these crops in disadvantaged areas suffering due to erratic rainfall, soil and marginal land not only provide a substantial employment as well as livelihood security to the farmers.

\section{Introduction}

Fiji is a relatively small island country in South Pacific Ocean comprising of more than 330 islands. The majority of the population is settled on the two largest islands Viti Levu and Vanua Levu, (Figure 1) creating a center of economic activity for the country, having
$90 \%$ of the population and $87 \%$ of the land area. Economic activity is dominated by agriculture, as is employment, with this sector directly employing $28 \%$ of the population and many more are employed indirectly. Earlier agriculture was main occupation contributing to economy, but now it ranks third. The agriculture sector was once dominated by 
sugarcane cultivation, but with its economic downfall and now contributing only $0.9 \%$ to the economy, and decreasing rapidly and replaced by other horticultural crops (Paras Nath, 2014). Fiji has numerous opportunities in horticulture according to the AusAid representative for market development facility (MDF) project (Beckers, 2011). MrBeckers opined that fruit and vegetables offers a vast local opportunity as well as for supplies into the tourism and export sectors. The Fijian climate is suitable to growing a number of tropical fruits and as such fruit production is now being recognized as a sustainably profitable enterprise in Fiji with great potential to generate employment in rural areas. This may also be helpful in reducing migration of rural masses towards cities for the want of jobs, and also to improve the quality of diet for Fijians. Mango and papaya are widely grown fruit crops specially in tropical regions, Fiji also has great potential to cultivate these crops. However, these crops are perishable in nature therefore post-harvest treatment should be required after harvesting in order to reduce post-harvest loess of these crops (Champathi and Tiwari, 2018; Champathi, et al., 2018).

But substantial areas in Fiji are classified asa Dry Zone which receives less average rainfall throughout the year than other parts of the country. Farmers of the dry-zone are entirely dependent on stored water in the soil and rainfall to meet the requirements of crop production. They are therefore subject to the vagaries of nature. In addition, environmental limitations such as poor soil structure, soil fertility, salinity, erratic rainfall, high wind velocity and temperature are major hindrances in sustainable crop production. The dry-zone lands can potentially be used for production of some hardy perennial fruit species which are a rich source of antioxidants and other health promoting phytochemicals (neutraceuticals). Figure 1 shows the major agricultural crops grown in Fiji Islands. Many of the fruit species such as bael, ber, kathal, custard apple, jamun, guava (see Table 1 for full descriptions) found growing in dry rain fed areas of Fiji have been found to yield satisfactorily under stressful agro-climatic conditions owing to their capacity to tolerate biotic stresses.

Some of these species have been domesticated to the cultivation level while others need to be domesticated and commercially exploited for the economic benefit of resource poor farmers of these regions. This group of such underutilized fruit crops will be referred as Future Fruit Crops. The term "Future Fruit Crops" is applied in the general sense, to a group of crops presently growing in a scattered and unattended way in Fiji's dryzone and can also be found on homestead land and wasteland in spite of their potential for commercial exploitation.

The plants belonging to this group are hardy and grow well even in fragile soil and climate. Conversely, the majority of these future fruit crops found abundantly in the dry tropical environment is unknown in other parts of country and is seldom seen in local markets. Today, due to higher awareness, consumers have become more particular about produce and health conscious and they wanted to fill their food basket with nutritionally rich fruits. Most of these dry tropical fruits are hardy in nature and contain both nutritive and therapeutic properties and can potentially satisfy the mineral nutrition of health conscious people.

Hence, there is a need to intensify research efforts to build knowledge of these underutilized fruit crops in the Fijian economy and support diversification. This can be achieved through improved value chain approach increase produce acceptability in both traditional and international markets. 


\section{Present Scenario}

In Fiji, a sizeable area is classified as the dry zone particularly $\mathrm{Ba}$, Nadroga and $\mathrm{Ra}$ province on Western side of VitiLevu and Bua, Macuata province in Northern side of Fiji (Fig. 1). Farmers are facing a number of production issues especially soil alkalinity/salinity, soil acidity, wind water erosion (Anonymous, 2009) and broader climate change issues including cyclone events. Consequently, many farmers are unable to harness the full potential from their lands and crops.

Productivity of the crops is also affected through poor farmer knowledge or uptake of technological advancements and most of farmers are subsistence farming. The strategy in these areas should therefore be oriented towards development of minor fruit crop based models for higher production and income generation as they have an inherent capacity to perform better in some adverse conditions. A number of germplasm exhibiting variant characters of ber, bael, jamun, guava, custard apple and other minor tropical fruit crops are available in Fiji which are primitive cultivars or land races showing diversity in their characters since most of them are propagated by seed over many generation.

Therefore, seedling variability available in country can be utilized through intensive research efforts. At the same time production technology with regard to plant propagation, tree architecture management, integrated orchard, insect-pest and disease management will need to be intensified.

\section{Importance and scope}

Provides basic necessities of resource poor farmers.

Assured production will be helpful in alleviating poverty.
Ensures livelihood as well as nutritional security.

Improvement of soil structure and thus soil health and sustainability.

Providing increased availability of fruit thus reducing malnutrition.

Enhancement in the socio-economic life of farmer.

\section{Considerations for sustainable production}

Avoidance or adaptive mechanisms against drought e.g. deep root system as in ber and jamun.

Summer dormancy as in ber, mulberry, custard apple for tolerance to high temperature or attainment of summer dormancy after pollination and fertilization.

High water holding capacity in leaf cells.

Maximum vegetative and reproductive growth of plant coinciding with the rain period

e.g. ber, custard apple.

Amenability of the plants for such coincidence by cultural manipulations through flowering treatments e.g. pomegranate, acid lime, sweet orange, guava (Mishra et al., 2016).

Guava has a capacity to tolerate and give better performance under varying climatic condition particularly in warm weather (Samson, 1986). Guava is very suitable for growing in dry part of Fiji (Barrau, 1955)

\section{Therapeutic properties and value addition}

In view of the growing cost of health care, consumers consider their food should have all the component of a healthy diet. 
Table.1 Future fruit crops for dry areas of tropics

\begin{tabular}{|c|c|c|c|c|c|}
\hline Crops & $\begin{array}{l}\text { Common } \\
\text { name }\end{array}$ & Botanical Name & Family & Origin & Reference \\
\hline Bael & Bael & Aeglemarmelos & Rutaceae & India & $\begin{array}{l}\text { Mishra et } \\
\text { al., } 2016\end{array}$ \\
\hline Ber & Ber & $\begin{array}{l}\text { Ziziphus } \\
\text { mauritiana }\end{array}$ & Rhamnaceae & $\begin{array}{l}\text { Indo } \quad- \\
\text { china }\end{array}$ & $\begin{array}{l}\text { Mishra et } \\
\text { al., } 2016\end{array}$ \\
\hline \multirow[t]{4}{*}{$\begin{array}{l}\text { Custard } \\
\text { apple }\end{array}$} & Sweet Sop & Anonasquamosa & Anonaceae & $\begin{array}{l}\text { South } \\
\text { America }\end{array}$ & \multirow{4}{*}{$\begin{array}{l}\text { Landauer } \\
\text { and Brazil, } \\
1990\end{array}$} \\
\hline & Sour sop & Anonamuricata & “ & 66 & \\
\hline & $\begin{array}{l}\text { Bullock's } \\
\text { heart }\end{array}$ & Anonareticulata & “ & “6 & \\
\hline & Cherimoya & Anonacherimoliya & “6 & “6 & \\
\hline \multirow[t]{2}{*}{ Guava } & Guava & Psidiumguajava & Myrtaceae & $\begin{array}{l}\text { Tropical } \\
\text { America }\end{array}$ & $\begin{array}{l}\text { Samson } \\
1986\end{array}$ \\
\hline & $\begin{array}{l}\text { Catalay or } \\
\text { Cherry/ } \\
\text { Strawberry } \\
\text { Type }\end{array}$ & $\begin{array}{l}\text { Psidium } \\
\text { cattelianum }\end{array}$ & myrtaceae & India & $\begin{array}{l}\text { Landauer } \\
\text { and Brazil, } \\
1990\end{array}$ \\
\hline Jamun & $\begin{array}{l}\text { Jambolan or } \\
\text { java plum }\end{array}$ & Syzygiumcuminii & Myrtaceae & India & $\begin{array}{l}\text { English et } \\
\text { al., } 1996\end{array}$ \\
\hline Jackfruit & Kathal & $\begin{array}{l}\text { Artocarpushetero } \\
\text { phyllus }\end{array}$ & Moraceae & $\begin{array}{l}\text { India and } \\
\text { Malaysia }\end{array}$ & $\begin{array}{l}\text { Stanton } \\
1986\end{array}$ \\
\hline$\overline{\text { Kavika }}$ & Malay apple & $\begin{array}{l}\text { Syzygiummalacce } \\
\text { nse }\end{array}$ & Myrtaceae & Malaysia & $\begin{array}{l}\text { Samson } \\
1986\end{array}$ \\
\hline $\begin{array}{l}\text { Lasora/Gond } \\
\text { a }\end{array}$ & lasora & Cordiamyxa & Boraginaceae & India & $\begin{array}{l}\text { Mishra et } \\
\text { al., } 2016\end{array}$ \\
\hline Mulberry & Mulberry & Morus spp. & Moraceae & China & $\begin{array}{l}\text { Mishra et } \\
\text { al., } 2016\end{array}$ \\
\hline $\begin{array}{l}\text { Nandau } \\
\text { (Pacific } \\
\text { lychee) }\end{array}$ & Dawa & Pometiapinnata & Sapindaceae & $\begin{array}{l}\text { Asia } \\
\text { pacific }\end{array}$ & $\begin{array}{l}\text { Henderson } \\
\text { and } \\
\text { Hancock, } \\
1989\end{array}$ \\
\hline Passion fruit & Passion fruit & Passifloraedulis & Passifloraceae & $\begin{array}{l}\text { South } \\
\text { America }\end{array}$ & $\begin{array}{l}\text { Stanton, } \\
1986\end{array}$ \\
\hline Star apple & Carambola & $\begin{array}{l}\text { Averrhoa } \\
\text { carambola }\end{array}$ & Oxaliaceae & $\begin{array}{l}\text { Malaysia } \\
\text { and south } \\
\text { east Asia }\end{array}$ & $\begin{array}{l}\text { Darley, } \\
1993, \\
\text { Stanton } \\
1986\end{array}$ \\
\hline Tamarind & Imli & Tamarindusindica & Caesalpiniaceae & India & $\begin{array}{l}\text { Malolo et } \\
\text { al., } 2001\end{array}$ \\
\hline Tarawau & Tarawau & $\begin{array}{l}\text { Dracontomelomvi } \\
\text { tianse }\end{array}$ & Anacardiaceae & $\begin{array}{l}\text { Tropical } \\
\text { Asia }\end{array}$ & $\begin{array}{l}\text { English et } \\
\text { al., } 1996\end{array}$ \\
\hline
\end{tabular}


Table.2 Therapeutic properties and value added products from Future Fruit Crops

\begin{tabular}{|c|c|c|c|}
\hline Future fruit crops & Therapeutic properties & Value added & Reference \\
\hline Jamun & $\begin{array}{l}\text { Diarrhoea can be cured by using fruit's } \\
\text { syrup. } \\
\text { Jambosin an alkaloid slows down the starch } \\
\text { conversion into sugars. } \\
\text { Jamun fruits are effective in liver, heart and } \\
\text { diabetes trouble. }\end{array}$ & $\begin{array}{l}\text { Squash, RTS, nectar, } \\
\text { syrup, vinegar, cider }\end{array}$ & $\begin{array}{l}\text { Mishra et al., } \\
2016,\end{array}$ \\
\hline Guava & $\begin{array}{l}\text { - Guava is ample source of vitamin }-\mathrm{C} \text {, and } \\
\text { contains substantial amount of dietary fibre, } \\
\text { carotene and Potassium } \\
\text { The leaves of guava are used for curing } \\
\text { diarrhea. } \\
\text { - Guava fruit contains antioxidant factor and } \\
\text { is known to control systolic blood pressure. }\end{array}$ & $\begin{array}{l}\text { Guava cake, Jam, } \\
\text { Jellies and making } \\
\text { juice. }\end{array}$ & $\begin{array}{l}\text { Bal,2006 } \\
\text { Dignan et } \\
\text { al., } 1994\end{array}$ \\
\hline Custard apple & $\begin{array}{l}\text { - The ripe fruits rich in tannins, which is } \\
\text { dried, pulverized and employed against } \\
\text { diarrhea and dysentery. Contains } \\
\text { considerable amount of Vitamins and } \\
\text { minerals }\end{array}$ & $\begin{array}{l}\text { Jam, beverages, ice } \\
\text { cream, sop puree, } \\
\text { soursop sorbet }\end{array}$ & $\begin{array}{l}\text { Mishra et al., } \\
\text { 2016, Dignan et } \\
\text { al., } 1994\end{array}$ \\
\hline Kawika & $\begin{array}{l}\text { - Kavika a source of Vitamin } \mathrm{C} \text { and some } \\
\text { minerals }\end{array}$ & $\begin{array}{l}\text { Eaten fresh, salad or } \\
\text { as dessert }\end{array}$ & $\begin{array}{l}\text { English et al., } \\
1996\end{array}$ \\
\hline Nandau & - $\quad$ Masticated bark is applied on burns & $\begin{array}{l}\text { Eaten fresh as a } \\
\text { snack, in salad }\end{array}$ & $\begin{array}{l}\text { Malolo et al., } \\
2001\end{array}$ \\
\hline Passion fruit & $\begin{array}{l}\text { - Source of dietary fibre more than lime } \\
\text { orange and mandarin }\end{array}$ & $\begin{array}{l}\text { Passion fruit syrup, } \\
\text { sauce }\end{array}$ & $\begin{array}{l}\text { Malolo et al., } \\
2001\end{array}$ \\
\hline Star apple & $\begin{array}{l}\text { - Source of vitamin - C, dietary fibre and } \\
\text { minerals }\end{array}$ & Juice, jams, pickles & $\begin{array}{l}\text { Malolo et al., } \\
2001\end{array}$ \\
\hline Bael & $\begin{array}{l}\text { - Useful in curing of stomach problem, } \\
\text { dysentery and diarrhea. }\end{array}$ & $\begin{array}{l}\text { Sharbat, squash, } \\
\text { murabba, jam }\end{array}$ & $\begin{array}{l}\text { Malolo et al., } \\
2001\end{array}$ \\
\hline Ber & $\begin{array}{l}\text { - Fruits are effective in relieving chest pain } \\
\& \text { vomiting sensation. } \\
\text { It is used widely in ayurveda and chinese } \\
\text { medicine. }\end{array}$ & $\begin{array}{l}\text { Murabba, candy, } \\
\text { dehydrated ber }\end{array}$ & $\begin{array}{l}\text { Mishra et al., } \\
2016\end{array}$ \\
\hline Tamarind & $\begin{array}{l}\text { - Contains tannnins, saponins, sesquiterpenes } \\
\text { and alkaloids } \\
\text { Used widely in cardioprotective digestion } \\
\text { or gastric problems in ayurveda. } \\
\text { Used as a decoctfor treatment of stomach } \\
\text { problem, pain, jaundice, yellow fever and } \\
\text { as blood tonic, skin cleanser and in malaria. }\end{array}$ & $\begin{array}{l}\text { Juice concentrate, } \\
\text { pulp powder, jam } \\
\text { syrup, candy, } \\
\text { tamarind kernel } \\
\text { powder }\end{array}$ & $\begin{array}{l}\text { Mishra et al., } \\
2016\end{array}$ \\
\hline Jackfruit & $\begin{array}{l}\text { - A good source of isoflavonoids, ascorbic } \\
\text { acid and vitamin A. } \\
\text { Improves immune system \& protect from } \\
\text { cancer. } \\
\text { - Aids in healthy digestion. } \\
\text { - Helps in eye health, skin \& Asthma. } \\
\text { Jackfruit has high sugar content than other } \\
\text { fruit and yields 80kcal per } 100 \mathrm{~g}\end{array}$ & $\begin{array}{l}\text { Canned pieces, } \\
\text { nectar, pickle \& } \\
\text { chips }\end{array}$ & $\begin{array}{l}\text { English and } \\
\text { Lewis } 1991\end{array}$ \\
\hline Mulberry & $\begin{array}{l}\text { - Resveratol an antioxidant found in } \\
\text { mulberries, helps to promote heart health } \\
\text { and overall vitality. }\end{array}$ & Juice, squash, syrup & $\begin{array}{l}\text { Mishra et al., } \\
2016\end{array}$ \\
\hline
\end{tabular}


Fig.1 Agricultural land use of Fiji Islands

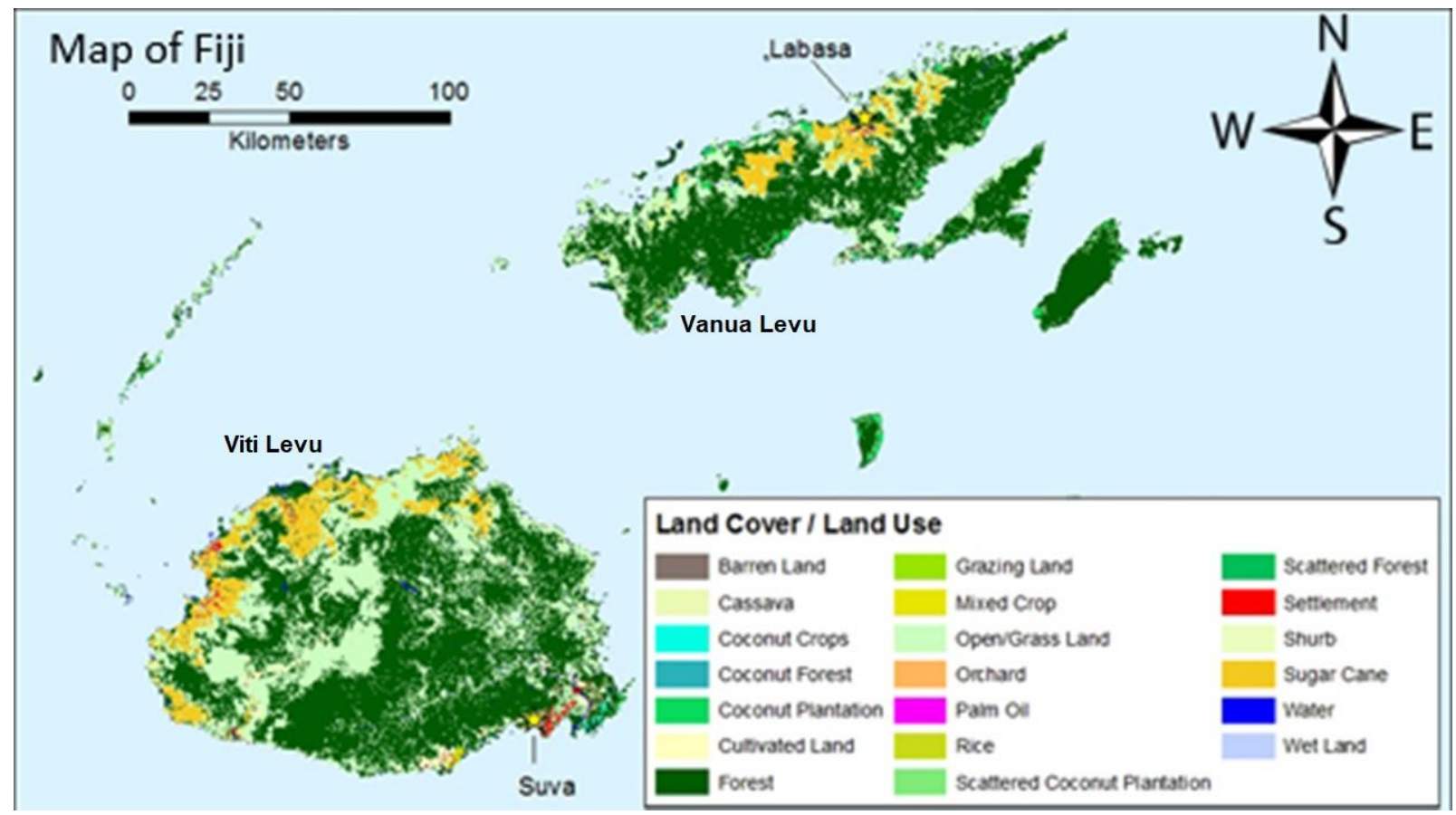

(Source: Ministry of land and mineral resources)

In this regard underutilized indigenous fruits can be a rich source of vitamins and minerals, and other therapeutically important elements considered good for human health (see Table 2). Consumer awareness on the health and fruit contribution to managing lifestyle diseases makes the underutilized fruit more important, adding value in their marketability and their consumption should be encouraged. Value added products from such fruits are high in demand in national and international markets.

Some of the important factors for orchard establishment in a dry zone need to be applied to minimize risk for farmers. Establishing a new orchard in a fragile ecosystem of the dry tropics is relatively difficult. Therefore, under such circumstances, in situ budding/grafting is preferred for most fruit species. This practice ensures development of deep, well distributed and extensive root systems for new plantings. The technique has been standardized in various fruits like ber, aonla, bael, manila tamarind, khirni and custard apple (Singh et al., 2016).

Multi-cropping systems are advised for risk minimization especially under fragile ecosystem of dry areas where uncertainty in production is high and mono-crop culture may not be advisable. Crop failures due drought are common and often leading to considerable economic loss.

Adoption of multi-cropping systems can help in improving the fertility of marginal land by selectively aligning crops to soil characteristics and adding biomass to improve soil fertility and health. Multi-cropping can also play an active role in reducing runoff reducing soil loss through erosion, and by sequestering $\mathrm{CO}_{2}$, from the atmosphere which contributes to the overall health of our environment. During the orchard establishment period, short statured crops like guava and acid lime can be planted as filler crops or leguminous vegetables (cow pea, 
cluster bean)/ pigeon pea, maize/ seed spices (cumin, fennel, methi)/medicinal and aromatic plants can be raised as inter-crops.

Integrated crop management systems also need to be considered, this includes the alignment to market standards such as organic certification or Fairtrade as appropriate. This may include, but is not limited to, practices like canopy management, IPNM, integrated pest and disease management, soil management practices and plant genetic materials to suit the location.

\section{References}

Anonymous, 2009. Report on Fiji national agriculture Census. Department of Agriculture, Fiji.

Bal, J.S. 2006. Fruit growing, Kalyani publishers, India.

Barrau, J. 1955. Subsistence Agriculture in Melanesia. South Pacific Commission, Noumea.

Beckers, H.2011. Horticultural potential. Fiji Sun, 29 November, 2011 File under: Business posted by Ana Madigibuli, Newsroom.

Champathi Gunathilake D.M.C., Tiwari A.K. and Tharanga Kahandawala, K.A. 2018 Efficacy of washing treatment for extending the post-harvest shelf-life of papaya (Carica papaya), Int. J. of Chemical Studies, 6(4) Pp 229-635.

Champathi Gunathilake, D.M.C. and Tiwari A.K., (2018) Efficacy of $\mathrm{BiOWiSH}^{\mathrm{TM}}$ washing treatment for extending shelflife of mango., Int. J. Curr. Microbiol. App. Sci 7(1) 613-619.

Darley, J.J. 1993. Know and Enjoy Tropical Fruits: Tropical Fruits and Nuts: a Cornucopia. P \& S Publishing, Thuringowa, Queensland.

Dignan, C.A., B.A. Burlingame, J.M. Arthur, R.J. Quigley and G.C. Milligan. 1994. The Pacific Islands Food Composition
Tables. South Pacific Commission, Noumea, New Caledonia; New Zealand Institute of Crop and Food Research, Ltd; and International Network of Food Data Systems, Palmerston North, New Zealand.

English, R.M. and J. Lewis. 1991. Nutritional Values of Australian Foods. Department of Community Services and Health, Australian Government Publishing Service, Canberra.

English, R.M., W. Aalbersberg and P. Scheelings. 1996. Pacific Island Foods. Description and Nutrient Composition of 78 Local Foods. Institute of Applied Sciences, University of the South Pacific and Australian Centre for International Agricultural Research, Australian Government Analytical Laboratories. Technical Report 96/02.

Henderson, C.P. and I.R. Hancock. 1989. A Guide to the Useful Plants of Solomon Islands. Research Department, Ministry of Agriculture and Lands, Honiara, Solomon Islands.

Landauer, K. \& M. Brazil (eds.). 1990. Tropical Home Gardens. United Nations University Press, Tokyo.

Malolo, M., R. Bishop, E. Telmetang, J. Bale, B. Chiokai, E. Kalosang, R. Louch \& M. Emesiochl. (1995). Palauan Foods Naturally the Best. South Pacific Commission, Noumea, New Caledonia.

Malolo, M.O, Smith, T.M and Schultz, J.T. 2001. The fruits we eat, Handbook / Secretariat of the Pacific community, Viewed on $10^{\text {th }}$ September 2017 WWW.spc.int

Mishra, D.S., Singh, S., Singh, A.K. and Yadav, V. 2016. Future fruit crops for semi-arid conditions of western India. In: Lakhawat, S.S. (ed.) Exploitation of underutilized fruit crops of arid and semi-arid region, MPUAT, Udaipur, pp. 187-192. 
Nath Paras. 2014. Horticulture potential in Fiji Islands, Progressive Horticulture, 46(2): 175-183

Samson, J.A. 1986. Tropical Fruits. Tropical Agricultural Series. Longman Scientific and Technical, New York.
Singh, A.K., Singh, S., Mishra, D.S. and Saroj, P.L. 2016. In rainfed semi-arid region: More crop with minimal water. Indian Horticulture, 61(6):86-91.

Stanton, R. 1986. Complete Book of Food and Nutrition. Simon \& Schuster, Australia.

\section{How to cite this article:}

Tiwari, A.K., D.S. Mishra, Salesh Kumar and Champathi Gunathilake, D.M.C. 2018. Exploitation of Climate Resilient Minor Tropical Fruit Crops for Nutritional and Livelihood Security in Fiji Islands. Int.J.Curr.Microbiol.App.Sci. 7(11): 2135-2142.

doi: https://doi.org/10.20546/ijcmas.2018.711.240 